\title{
Cancer and yerba mate consumption: a review of possible associations
}

\author{
Dora Loria, ${ }^{1}$ Enrique Barrios, ${ }^{2}$ and Roberto Zanetti ${ }^{3}$
}

Suggested citation Loria D, Barrios E, and Zanetti R. Cancer and yerba mate consumption: a review of possible associations. Rev Panam Salud Publica. 2009;25(6):530-9.

ABSTRACT Objective. To identify any possible link between mate consumption and cancer, mainly of the esophagus, larynx, and oral cavity.

Methods. A review of literature, published through August 2008, pertaining to the carcinogenic risk of mate consumption was undertaken by searching the two databases, MEDLINE and TOXLINE, for relevant articles. The bibliographies of the articles were examined for additional relevant sources. In addition, a search on the name of each author having published on the topic was conducted. The epidemiological studies are presented by cancer site; experimental works are examined in dedicated sections; and the discussion combines epidemiological and experimental evidence.

Results. Almost all epidemiological studies shared similar methodology: hospital-based, case-control studies where participants were personally interviewed on the main risk factors, using similar questionnaires. Several studies found an association between the temperature of the mate infusion and oral, esophageal, and/or laryngeal cancer risks; while a few focused on carcinogenic contaminants introduced during the industrial processing of the leaves. The cancer most frequently mentioned in association with hot mate with bombilla (drunk through a metal straw) was the esophagus. Size, exposure assessment, methods of analysis, and quality were different among the studies reviewed. The results varied greatly. The higher risk estimate (odds ratio $=34.6$ ) was found for women who drank $1 \mathrm{~L}$ or more daily; for men it was only 4.8. Risk increased with duration, daily quantity, and temperature at drinking. The synergic action between mate, alcohol, and tobacco was a clear result in several studies, and in some, nutritional deficiencies and poor oral hygiene played a role. No increased risk was associated with cold mate beverages.

Conclusions. The role of hot mate in increasing the risk of cancer of esophagus, larynx, and oral cavity seems to be supported by several epidemiological studies. The temperature could act by damaging the mucosa or accelerating metabolic reactions, including those with carcinogenic substances in tobacco and alcohol. However, there is no sound population-based casecontrol study on mate consumption as a risk factor for cancer. This, coupled with the range of results on mate risk, make assessing the etiological fraction difficult. More research needs to be done before a definitive statement can be made regarding cancer risk associated with any of the various forms of mate consumption. Future research should include population-based studies; collection of data on consumption of tobacco, alcohol, hot drinks, fresh fruit, and vegetables; and, a method to precisely measure volume and temperature of mate intake.

Key words Laryngeal neoplasms, esophageal neoplasms, pharyngeal neoplasms, Ilex paraguariensis, review literature, Argentina, Brazil, Paraguay, Uruguay.

1 Instituto de Oncología "Ángel H. Roffo," Buenos Aires, Argentina. Send correspondence to: Dora Loria, Universidad de Buenos Aires, Instituto de Oncología "Ángel H. Roffo," Av. San Martin 5481, Buenos Aires 1417, Argentina; telephone: +54-116568-6773; fax: + 54-11-4580-2811; email: loradora@ yahoo.com
Mate is a beverage made from the leaves of a perennial shrub-tree (Ilex paraguarien-

\footnotetext{
2 Departamento de Métodos Cuantitativos, Facultad de Medicina, Montevideo, Uruguay.

3 Director Piedmont Cancer Registry, Center for Cancer Prevention, Turin, Italy.
}

sis) native to Argentina, Brazil, Paraguay, and Uruguay. The Spanish word mate refers to the dried leaves (also called yerba mate), as well as the cup from which the beverage is drunk, traditionally a small, hollow gourd. Mate is consumed in vari- 
ous ways, but the most popular method is by placing the yerba mate in the cup (the aforementioned gourd, or a metal, silver, or ceramic vessel shaped like small jug), pouring boiling water into it, and sipping the infused liquid through a metal straw called a bombilla (little pump). The bombilla acts as a filter-the end that goes into the liquid has a bulb pierced with small holes that prevents the leaves from going up the straw. Hot water is added to the mate mainly in Argentina, Brazil, and Uruguay; this type of preparation is called mate con bombilla. On the other hand, mate can also be a cold beverage (terere), a habit common in Paraguay. Sugar or an artificial sweetener may also be added, though in Brazil, the mate is traditionally drunk without sugar (cimarrao). The number of times that additional boiling water is poured into the same serving of yerba mate differs according to individual preference. In addition, mate may be prepared and drunk like a common tea (mate cocido). Grocery stores in these countries carry commercial mate products with differing amounts of twigs/stems and a variety of flavors, e.g., orange peel.

A flowchart of the industrial processing of Ilex paraguariensis leaves and a description of the main compounds found in mate can be found in a recent paper by Heck and Mejia (1). A report of the National Institute for Yerba Mate in Argentina provides details of the plant and its cultivation, the production processes, the chemical composition of the resulting commercial products, and the various consumption habits (2). Although mate is predominantly a South American habit, commercial products are entering the markets in countries outside the continent.

In 1991, the International Agency for Research of Cancer (IARC) evaluated the carcinogenic risk of mate and concluded that: (a) there is "limited evidence for carcinogenicity of hot mate drinking in humans;" (b) "no data available on the drinking of cold mate;" and, (c) "no data on its carcinogenicity in experimental animals" (3). Overall, IARC classified drinking hot mate as "probably carcinogenic to humans (Group 2A)" and mate as "not classifiable as to its carcinogenicity to humans (Group 3)." Most of the studies on which the IARC evaluation was based were similar in methodology and shared part of the enrolled subjects and some of the researchers. As of $\mathrm{Au}-$ gust 2008, the IARC has not released an updated evaluation; however some new studies have been published, showing heterogeneous results. Incidence rates for cancer of the esophagus, larynx, and oral cavity-the cancers mostly related to mate ingestion-vary among Latin American countries. Examples are provided in Figure 1 and are compared with the corresponding data for North America (4).

The main objective of this study was to systematically and analytically review the literature published to date to identify any possible link between mate consumption and cancer, mainly of the esophagus, larynx, and oral cavity.

\section{MATERIALS AND METHODS}

A review of literature pertaining to the carcinogenic risk of mate consumption was undertaken by searching the two databases, MEDLINE and TOXLINE, with key words and the strings "mate \& cancer" and "yerba mate \& tumors" for relevant articles. The bibliographies of the articles were examined for additional relevant sources. In addition, a search on the name of each author having published on the topic was conducted.

All of the resulting epidemiological works published by indexed journals were considered for the review. Of the clinical and the toxicological studies (conducted on humans, in experimental mammals, and in vitro), those that offered an explanation of the epidemiological findings were retained.

Though the epidemiological articles were a non-negligible number, the decision to override the conditions for a formal meta-analysis was made because (a) not all the studies were independent, some being an extension of, combined with, or new analysis of a previous study; (b) the studies varied greatly in terms of design, methods, and techniques of exposure assessment; and, (c) the size of some case-control studies was limited. Therefore, we proceeded with a traditional review, considering the following for each article:

- Population targeted

- Time-period covered

- Study design

- Sample size

- Method of exposure assessment

- Statistical analysis

- Results and their statistical significance

- Sources of possible bias

- Analysis and discussion elements

This review presents the epidemiological studies by cancer site (esophagus; oral cavity, oropharynx, and larynx; bladder; other cancers). Experimental works are examined in dedicated sections. The discussion combines epidemiological and experimental evidence.

\section{RESULTS}

\section{Epidemiological studies}

In terms of study design, most of the studies evaluated were hospital-based case-control studies with customized questionnaires used by trained interviewers. Epidemiological studies are presented by tumor site and results are summarized in Tables 1, 2, and 3.

Esophageal cancer. This was the cancer most frequently mentioned in association with mate consumption. One of the first papers published on patients with esophageal cancer was a hospital-based case-control study carried out in Uruguay in 1985 (5). The methodology applied was partially modified in following studies, to which some of the same authors contributed. A high odds ratio (OR), with a statistically significant confidence interval $(95 \% \mathrm{CI})$, was found for women who reported drinking $1 \mathrm{~L}$ or more mate per day $(34.6$; 95\%CI: 4.9246.5), while for men consuming the same amount, the risk was only 4.8 (95\% CI: 1.9-12.1). The authors suggest a synergic action between mate consumption and smoking.

Following this study, the IARC coordinated some additional studies in various countries in the Southern Hemisphere and found different results (6-8). One of these studies postulated an interesting hypothesis for explaining the greater effect of mate on smokers of dark tobacco, than on smokers of blond tobacco (7). The authors suggested that the root cause could be socioeconomic differences between the two types of smokers-in general, smokers at the lower socioeconomic levels smoke dark tobacco. They also eat diets poorer in fruits and vegetables, which have been recognized to protect against esophageal cancer. The study found no consistent relationship between effects and the temperature at which the individuals reported drinking the mate.

Some years later, De Stefani et al. carried out a study to assess the effect of certain dietary factors on the etiology of esophagus carcinoma, finding a statistically significant risk of about 2 for salted and stewed meat (9). The authors suggested that this effect, as would also be the case with mate, could be due to the 
FIGURE 1. Incidence rates of cancer of the esophagus, oral cavity, or larynx, adjusted by age (world standard population), and expressed as the number of new cases per 100000 individuals from 20-85 or more years of age (4)
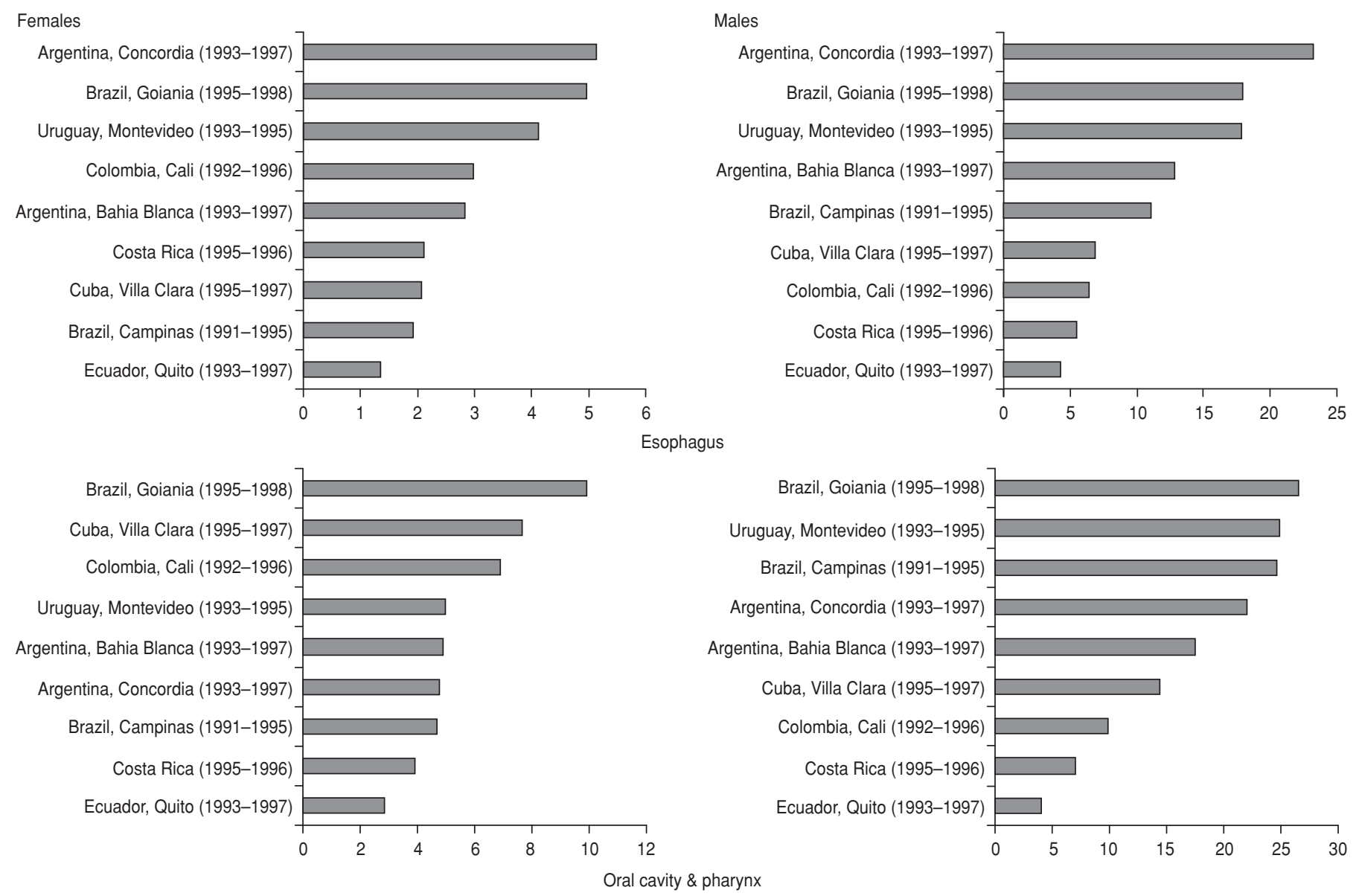

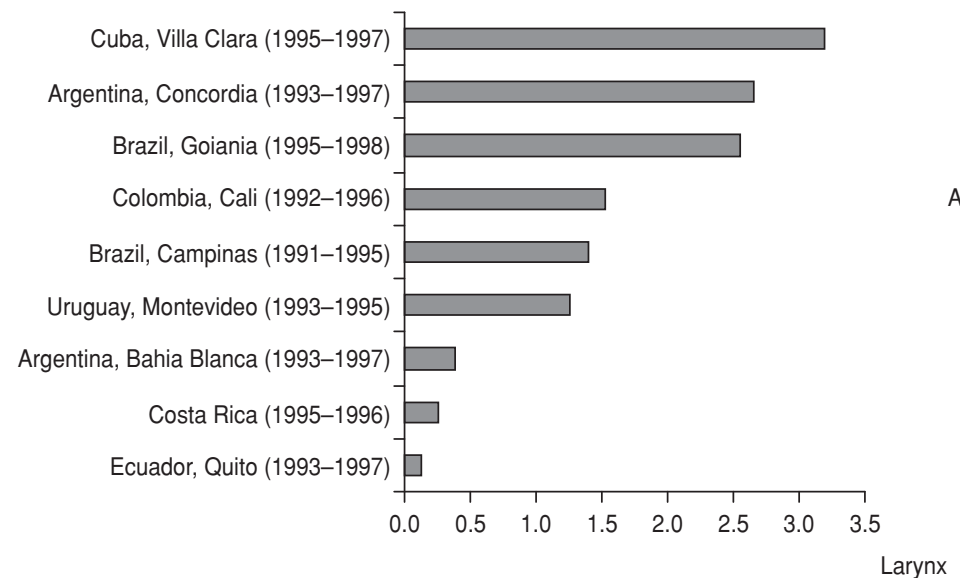

high temperature at which these foods are consumed. In a detailed study on the mate drinking habit and esophageal cancer occurrence, it was found that the risk increased with the duration of the habit, the daily quantity ingested, and the temperature of the drink (self-reported as "warm," "hot," or "very hot") (10). The authors noted that the temperature rating could have been affected by subjectivity. The risk for drinkers of more than $1 \mathrm{~L}$ of "very hot" mate per day was 2.95.
A more recent retrospective study was performed enrolling all esophageal cancer cases diagnosed at the Montevideo Cancer Institute in 1988-2000 (10). An association between mate consumption and esophageal cancer was found, signaling two independent factors: the temperature and the daily quantity of the mate drunk. The risk found for the individuals with higher accumulated exposure to mate was lower if they were less exposed to alcohol and tobacco (OR 1.52; 95\%CI:
0.88-2.62 versus OR 7.1; 95\%CI: 3.7513.00 if more exposed).

Of the series of studies conducted in Uruguay $(5,7,9-11)$, it is interesting to single out the one based on data of esophagus cancer patients who were not smokers or consumers of alcohol, thus excluding the two most important confounding factors: tobacco and alcohol consumption (11). The authors described a model where daily consumption (OR 2.20, 95\%CI: $1.02-4.91$, for $1 \mathrm{~L}$ or more 
TABLE 1. Summary of studies on mate intake and esophageal cancer in South America, by year of publication

\begin{tabular}{|c|c|c|c|c|c|c|c|c|c|}
\hline \multirow[b]{2}{*}{ Country } & \multirow[b]{2}{*}{ Year } & \multirow{2}{*}{$\begin{array}{c}\text { Number of } \\
\text { cases/controls }\end{array}$} & \multirow[b]{2}{*}{ Sex } & \multicolumn{3}{|c|}{ Mate intake } & \multirow[b]{2}{*}{$\mathrm{OR}^{\mathrm{a}}$} & \multirow[b]{2}{*}{$95 \% \mathrm{Cl}$} & \multirow{2}{*}{$\begin{array}{c}\text { Reference } \\
\text { number }\end{array}$} \\
\hline & & & & Unit quantity & Frequency & Temperature & & & \\
\hline \multirow[t]{2}{*}{ Uruguay } & 1985 & $175 / 313$ & Males & L/day & $\begin{aligned} & 0 \\
< & 0.5 \\
0.5-0.99 & \\
\geq & 1\end{aligned}$ & & $\begin{array}{l}1 \\
1.1 \\
3.1 \\
4.8\end{array}$ & $\begin{array}{l}0.2-5.0 \\
1.2-7.8 \\
1.9-12.1\end{array}$ & 4 \\
\hline & & $40 / 66$ & Females & & $\begin{array}{c}0 \\
0.001-0.499 \\
0.5-0.999 \\
\geq 1.000\end{array}$ & & $\begin{array}{c}1^{b} \\
2.1 \\
12.5 \\
34.6\end{array}$ & $\begin{array}{l}0.1-31.7 \\
2.0-80.1 \\
4.9-246.5\end{array}$ & \\
\hline Brazil & 1987 & $171 / 342$ & Both & & $\begin{array}{l}\text { Less than daily } \\
\text { Daily }\end{array}$ & & $\begin{array}{l}1 \\
1.47\end{array}$ & $0.87-2.5$ & 5 \\
\hline Uruguay & 1990 & $261 / 522$ & Both & L/day & $\begin{array}{c}0 \\
0.01-0.49 \\
0.5-1.49 \\
1.50-2.49 \\
\geq 2.5\end{array}$ & & $\begin{array}{r}1 \\
2.52 \\
3.60 \\
6.07 \\
12.21\end{array}$ & $\begin{array}{l}0.8-8.4 \\
1.3-9.9 \\
2.1-17.3 \\
3.8-39.6\end{array}$ & 6 \\
\hline Argentina & 1994 & $131 / 262$ & Both & & & $\begin{array}{l}\text { Warmc } \\
\text { Hot/very hot }\end{array}$ & $\begin{array}{l}1 \\
1.7\end{array}$ & $1.0-2.9$ & 7 \\
\hline Paraguay & 1995 & $127 / 370$ & Both & & $\begin{array}{l}\text { Mate and } \\
\text { mate cocido }\end{array}$ & $\begin{array}{l}\text { Warm/hot } \\
\text { Very hot }\end{array}$ & $\begin{array}{l}1 \\
2.4\end{array}$ & $1.3-4.3$ & 13 \\
\hline & & $101 / 298$ & Both & & Mate cocido & $\begin{array}{l}\text { Warm } / \text { hot }^{\mathrm{C}} \\
\text { Very hot }\end{array}$ & $\begin{array}{l}1 \\
6.5\end{array}$ & $3.2-13.2$ & \\
\hline $\begin{array}{l}\text { Argentina, Brazil } \\
\text { Paraguay, Uruguay }\end{array}$ & 2000 & $759 / 1538$ & Both & & Mate & $\begin{array}{l}\text { Cold/warm } \\
\text { Hot } \\
\text { Very hot }\end{array}$ & $\begin{array}{l}1 \\
1.11 \\
1.89\end{array}$ & $\begin{array}{l}0.84-1.47 \\
1.24-2.86\end{array}$ & 14 \\
\hline & & & & L/day & $\begin{array}{r}0-0.50 \\
0.51-1.00 \\
1.01-1.50 \\
>1.50\end{array}$ & & $\begin{array}{l}1^{\mathrm{d}} \\
0.95 \\
1.40 \\
1.58\end{array}$ & $\begin{array}{l}0.75-1.20 \\
0.99-1.98 \\
1.17-2.17\end{array}$ & \\
\hline & & $689 / 1466$ & & & & $\begin{array}{l}\text { Never very hot } \\
\text { Always very hot }\end{array}$ & $\begin{array}{l}1 \\
2.07\end{array}$ & $1.55-2.76$ & \\
\hline Uruguay & 2003 & $344 / 469$ & Both & L/day & & $\begin{array}{l}\text { Warm, hot } \\
\text { Very hot }\end{array}$ & $\begin{array}{l}1 \\
2.95\end{array}$ & $1.30-6.71$ & 9 \\
\hline Uruguay & 2004 & $73 / 219^{e}$ & Both & L/day & $\begin{array}{c}0-0.49 \\
0.50-0.99 \\
\geq 1\end{array}$ & & $\begin{array}{l}1 \\
1.60 \\
2.20\end{array}$ & $\begin{array}{l}0.67-3.58 \\
1.02-4.91\end{array}$ & 10 \\
\hline
\end{tabular}

adds ratio adjusted by age, alcohol, and tobacco.

${ }^{b}$ Without adjusting for tobacco and alcohol.

${ }^{c}$ Quantity independent.

d Joint effect of amount and temperature.

e Non-smokers, non-drinkers.

per day), duration of habit (OR 2.49, 95\%CI: $1.15-5.40$, for 60 or more years of habit), and intensity of habit (OR 1.91, 95\%CI: $1.06-3.45$ for more than $37 \mathrm{~L}$ per year) were the most relevant factors linked to risk.

A study conducted in the southern part of Brazil (6), found that there was a $50 \%$ increase in risk of esophageal cancer among the daily drinkers of mate con bombilla, but maybe because of the confounding effects of smoking and place of residence, the risk was not statistically significant (OR 1.47; 95\%CI: 0.87-2.5). The main risk factors for esophageal cancer in this geographic area were alcohol consumption, smoking habits, residing in a rural area, and a diet poor in fruit.

In a molecular epidemiological study also conducted in the south of Brazil, TP53 mutations different from those of the worldwide database were found in subjects with squamous cell carcinoma of the esophagus. The authors postulated that the presence of these mutational differences could be explained, at least partially, by the presence of a chronic inflammatory process due to mucosal irritation caused by the very hot mate commonly drunk in this area (12).

A pilot survey was carried out in healthy males to investigate the effects of hot beverages on the human esophagus (13). The histological exams performed on the esophageal mucosa of daily drinkers of hot mate, as well as nondrinkers, showed almost twice the number of esophagitis in drinkers. It has been postulated that the cause of the damage 
TABLE 2. Summary of studies on mate intake and oral and oropharyngeal cancer in South America

\begin{tabular}{|c|c|c|c|c|c|c|c|}
\hline \multirow[b]{2}{*}{ Country } & \multirow{2}{*}{$\begin{array}{c}\text { Year of } \\
\text { publication }\end{array}$} & \multirow{2}{*}{$\begin{array}{l}\text { Number of } \\
\text { cases/ } \\
\text { controls }\end{array}$} & \multicolumn{2}{|c|}{ Mate intake } & \multirow[b]{2}{*}{$\mathrm{OR}^{\mathrm{a}}$} & \multirow[b]{2}{*}{$95 \% \mathrm{Cl}$} & \multirow{2}{*}{$\begin{array}{c}\text { Reference } \\
\text { number }\end{array}$} \\
\hline & & & Unit & Quantity & & & \\
\hline Uruguay & 1988 & $108 / 286^{b}$ & L/day & $\begin{array}{c}<1 \\
1-1.99 \\
\geq 2\end{array}$ & $\begin{array}{l}1 \\
2.5 \\
5.2\end{array}$ & $\begin{array}{l}1.1-5.7 \\
2.1-13.1\end{array}$ & 26 \\
\hline Brazil & 1989 & $232 / 464^{c}$ & Mates/month & $\begin{array}{c}<1 \\
1-30 \\
>30\end{array}$ & $\begin{array}{l}1 \\
1.6 \\
1.6\end{array}$ & $\begin{array}{l}0.8-3.3 \\
0.8-3.3\end{array}$ & 30 \\
\hline Uruguay & 1991 & $57 / 353^{d}$ & L/day & $\begin{array}{c}<1 \\
1-1.99 \\
\geq 2\end{array}$ & $\begin{array}{l}1 \\
0.9 \\
2.5\end{array}$ & $\begin{array}{l}0.4-2.1 \\
1.2-5.6\end{array}$ & 27 \\
\hline Brazil & 1994 & $\begin{array}{l}378 / 756^{e} \\
160 / 338^{f}\end{array}$ & Mates/day & $\begin{array}{l}\text { Non-drinker } \\
\text { Drinker } \\
\text { Non-drinker } \\
\text { Drinker }\end{array}$ & $\begin{array}{l}1 \\
1.61 \\
1 \\
1.88\end{array}$ & $\begin{array}{l}1.2-2.2 \\
1.1-3.3\end{array}$ & 24 \\
\hline $\begin{array}{l}\text { a Odds ratic } \\
{ }^{b} \text { Orophary } \\
{ }^{c} \text { Oral cavit } \\
{ }^{d} \text { Tongue, } \\
\text { e All upper } \\
{ }^{f} \text { Mouth, bo }\end{array}$ & $\begin{array}{l}\text { Isted by age, } \\
\text { ales. } \\
\text { h sexes. } \\
\text { ligestive tract } \\
\text { xes. }\end{array}$ & $\begin{array}{l}\text { hol, and tobe } \\
\text { sexes. }\end{array}$ & & & & & \\
\hline
\end{tabular}

TABLE 3. Summary of studies on mate intake and laryngeal cancer in South America

\begin{tabular}{|c|c|c|c|c|c|c|c|}
\hline \multirow[b]{2}{*}{ Country } & \multirow{2}{*}{$\begin{array}{c}\text { Year of } \\
\text { publication }\end{array}$} & \multirow{2}{*}{$\begin{array}{c}\text { Number of } \\
\text { cases/ } \\
\text { controls }\end{array}$} & \multicolumn{2}{|c|}{ Mate intake } & \multirow[b]{2}{*}{$\mathrm{OR}^{\mathrm{a}}$} & \multirow[b]{2}{*}{$95 \% \mathrm{Cl}$} & \multirow{2}{*}{$\begin{array}{c}\text { Reference } \\
\text { number }\end{array}$} \\
\hline & & & Unit & Quantity & & & \\
\hline Uruguay & 1987 & $107 / 290$ & L/day & $\begin{array}{c}0-0.49 \\
0.50-0.99 \\
1.00-1.49 \\
\geq 1.50\end{array}$ & $\begin{array}{l}1 \\
3.2 \\
2.6 \\
4.9\end{array}$ & $\begin{array}{l}0.9-10.3 \\
0.8-8.2 \\
1.7-1.43\end{array}$ & 26 \\
\hline & & & & $\begin{array}{l}0-0.49 \\
>0.49\end{array}$ & $\begin{array}{l}1 \\
3.4\end{array}$ & $1.8-6.6$ & \\
\hline Brazil & 1994 & $97 / 194$ & Mates/day & $\begin{array}{l}\text { No } \\
\text { Yes }\end{array}$ & $\begin{array}{l}1 \\
2.24\end{array}$ & $1.15-4.50$ & 25 \\
\hline
\end{tabular}

a Odds ratio adjusted by age, alcohol, and tobacco.

was the thermal action of the beverage. The need for additional studies on a greater number of healthy individuals to validate these findings was suggested, but no such further studies have been published to date.

In Argentina, a hospital-based casecontrol study was conducted by Castelletto et al. (8), using a design similar to those used in Uruguay and Brazil (6, 7, 11). This study found an increased risk associated with tobacco and alcohol consumption, but not with mate drinking in general. However, after dividing the mate drinkers into two groups according to their individual perception of the temperature at which they drink their mate (warm vs. hot/very hot), and after adjusting for the effect of other factors, the authors found that the risk was higher for the group drinking it hot/very hot (OR 1.7; 95\%CI: 1.0-2.9).

A similar study was conducted in Paraguay considering the possible effects of both mate cocido (prepared as tea) drunk hot and mate con bombilla drunk hot or cold (14). One of the difficulties encountered in the analysis was that more than $88 \%$ of the respondents reported being drinkers of hot mate, and that the habit of drinking cold mate was also rather widespread; therefore, there were too few respondents who drank mate only hot or only cold. Because this hospital-based case-control study, excluded subjects with diseases potentially associated with tobacco and alcohol from the control group, a greater propor- tion of mestizos and tobacco and alcohol consumers were among the cases. Regardless, the authors were able to identify an increased risk of esophageal cancer among consumers of very hot mate (OR 2.4; 95\%CI: 1.3-4.3), independent of habit duration.

In 2000, a pooled analysis of the studies carried out in Latin American countries (15) was published, including 830 cases and 1779 controls. This analysis confirmed that alcohol and tobacco were the most influential factors in esophageal cancer; it also suggested that there is an increased risk associated with daily mate intake, especially when drunk hot. The same study quantified the risk due to the consumption of other hot drinks, finding that the risk increased rapidly among those that declared drinking tea or coffee with milk at very high temperatures. No excess risk was found for drinkers of very hot coffee alone. The authors suggested that this disparity in the results was probably linked to the lower volume of the hot liquid intake when the coffee is drunk alone. As early as 1972, a relationship was identified between an increase in the intraesophageal temperature and the coffee volume (16).

A detailed study (17) on the possible contribution of temperature of an infusion to the carcinogenic process showed that, for more than $70 \%$ of subjects, a thermometer immersed just prior to ingestion ranged from $51^{\circ} \mathrm{C}-78^{\circ} \mathrm{C}$. The study also showed that the temperature reported by the subject had only limited correspondence with the temperature indicated by the thermometer.

Temperature of infusion and esophageal cancer risk has also been studied in other continents, specifically with respect to tea consumption. A Japanese cohort study followed 220272 men from 1966-1981 (18). During that period, there were 440 deaths due to esophageal cancer, and a relative risk of 1.6 was found for hot green tea drinkers vs. those drinking tea at a moderate temperature. A low intake of green or yellow vegetables was also associated with an increased risk.

Several subsequent studies have investigated the role of fruit and vegetable consumption and the risk of esophageal, oral, and oropharyngeal tumors. The protective effect of a diet rich in fruits and vegetables has been evidenced by several population groups with very different dietary habits (19-21).

The role of thermal irritation due to very hot tea consumption, together with 
the promoting effect of tannins and the nutritional deficiencies, has also been found to be associated with the development of esophageal cancer in the coastal Caspian area of Iran (22). The Caspian area is known to have a high incidence of this cancer. However, the results of this study, undertaken with information from the 1968-1997 period, could have been affected by opium intake and consumption of bread contaminated with silica fibers. In China, the consumption of beverages and soups at high temperatures has also been found to be associated with an increased risk (2-3 times) of esophageal cancer (23).

Oral cavity, oropharynx, and larynx cancer. Tobacco and alcohol are well established as important etiological factors in these cancers also; but other factors, including viruses, could play an independent role or act as modifiers in the carcinogenic process. The HPV16 (a common type of papilloma virus found in genital mucosa) has been recently postulated as a risk factor (24).

Concerning beverages intake, Pintos et al. (25) analyzed the answers to a questionnaire administered to hospital cases and controls, finding some excess risk of developing oral and laryngeal cancer for mate drinkers, but not for tea or coffee drinkers. In the discussion, it was mentioned that the results could reflect the presence of confounding factors; for example, those individuals drinking larger quantities might tend to say they drank it less hot. In this study, the intake was quantified by the number of mates, instead of daily volume.

In a hospital-based case-control study (26), those drinking 1.5 L or more of very hot mate per day had nearly 5 times the risk for laryngeal cancer, after adjusting for alcohol and tobacco consumption (OR 4.9; 95\%CI: 1.7-14.3). There were no differential effects, whether the lesions were glottic or supraglottic. Phenolic compounds present in the mate were postulated to play a carcinogenic role, and the mate itself was postulated to be a solvent of the carcinogenic compounds contained in tobacco. Using the same methodology, the same authors studied the risk factors for oropharyngeal tumors, finding black tobacco, alcohol (wine and liquor), and mate consumption to be independent and statistically-significant factors (27).

Another study in Uruguay (28) found an increased risk for tongue cancer of 2.5 (95\% CI: 1.2-5.6), adjusted for tobacco, alcohol, and diet, among those drinking $2 \mathrm{~L}$ or more of mate per day (with no mention of the temperature of the drink or the habit duration).

A review published in 2001 has evaluated the incidence and mortality rates according to risk factors for mouth cancers in Latin America (29), paying particular attention to dietary factors such as red meat, particularly barbequed meat, and hot drinks. In the case of Brazil, WunshFilho stated that in addition to alcohol and tobacco consumptions, conditions present among low-income populationsnutritional deficiencies and poor oral hygiene-may play a part in an increase risk for oral cavity and pharyngeal cancers (30). Franco et al., again in Brazil, found that, after adjusting for alcohol and tobacco, the risk of oral cancer doubled for people who brushed their teeth infrequently versus those brushing daily (31).

In two other reviews, mate consumption was suggested to play a role in the development of oral and oropharyngeal cancers, although the exact process was not identified $(32,33)$.

Cancer of the bladder. The thermal injury hypothesis would not explain a higher risk of malignant tumors in organs that do not come into direct contact with the hot beverage. In a study aimed at assessing the role of different types of tobacco on bladder cancer (34), an increased risk was found relative to daily mate intake with a multiplicative association regarding number of cigarettes smoked. No excess of risk was reported for habit duration or age at onset. However, it was not possible to rule out some bias, for example, by including patients with other tumors as controls, rather than only healthy individuals.

In 2007, there was a new analysis (35) of a study published previously that had aimed to identify the possible effects of arsenic exposure on bladder cancer occurrence in Argentina (36). The research consisted of a case-control study, with hospitalized bladder cancer patients, residents of a geographic area where arsenic was present in the water. The consumption of mate cocido, as well as mate con bombilla, was studied during three periods of the subjects' lives: at the time of the survey, at 20 years prior to it, and at 40 years prior. It was found that there was no significant increased risk for mate cocido consumption. However, there was a 4-fold increased risk for smokers and alcohol drinkers (OR 3.77; 95\%CI: 1.17-
12.1) who were drinkers of mate con bombilla at least 20 years prior to the study.

Another study, carried out in Argentina (37) in 1983-1985, evaluated the effect of the tobacco habit and exposure to certain occupational hazards on the occurrence of bladder cancer; mate intake, taken into account as a possible risk factor, did not increase the risk.

Other cancers. The effect of mate was also considered in a case-control study carried out in Uruguay on patients with kidney cancer (38). It was found that there was a 3-fold increased risk, adjusted for other factors, for individuals that reported drinking $2 \mathrm{~L}$ or more of mate per day. The authors postulated that the presence of caffeic acid and/or the diuretic effect of mate could be associated with increased risk.

The same authors, using the same questionnaire, found an association between lung cancer risk and mate consumption (both quantity and habit duration as risk factors) (39). The effect was more evident in the small cell and squamous cell type lung cancer patients than in adenocarcinoma lung cancer patients. In this study, the presence of Benzopyrene (BP), a carcinogenic polycyclic aromatic hydrocarbon (PAH) in mate was postulated to be a possible action mechanism.

In 1974-1975, an ecological study (40) was conducted in several cities in Brazil to assess the association between cancer mortality and dietary factors. An association was found between chimarrão (unsweetened mate) and esophageal, colon, and lung cancer mortality; however, the results may be influenced by ecological bias.

\section{Studies on the prevalence of consumption}

A survey of 719 randomly-selected households in the south of Brazil collected data on the prevalence of different modalities of mate drinking (41). A questionnaire was administered to 1388 participants, $33.6 \%$ of whom were not drinkers of mate. In the homes in which at least one mate drinker was present, one subject was asked to complete a more detailed questionnaire. A higher frequency of consumption and a higher temperature of ingestion were found in men (an average of $71.1^{\circ} \mathrm{C}$ in men vs. $67.6^{\circ} \mathrm{C}$ in women, $P<0.001$ ). The survey also found a higher daily volume drunk among individuals who were also alcohol drinkers or cigarette smokers. 
A small, descriptive study conducted in northeastern Argentina (42), where mate drinking is very prevalent, collected the clinical histories of 117 cases of esophageal cancer, with little data on mate consumption. This study cannot be used to estimate either the prevalence (since cases were recruited on a hospital basis) or the relative risk (since no control group was included).

\section{Other studies}

Clinical/experimental (in vivo: humans and animals). The possible genotoxic activity of mate was studied in samples drawn from the esophageal mucosa; the patients were interviewed on their habits after the endoscopy (43). The findings indicated a higher frequency of micronucleus among the tobacco smokers and mate drinkers; however, the significance of the micronucleus in tumor occurrence has still to be understood.

Commercial forms of yerba mate could contain PAH due to the drying process $(1,2)$. As early as 1941, research by Dr. Angel Roffo referred to the tar content of yerba mate extracts and the occurrence of skin tumors in experimental animals painted with a yerba mate mixture (44).

In another study, a metabolite of BP, 1-hydroxypyrene glucuronide, was found in urine samples of healthy individuals (45). Its concentration varied according to cigarette and mate consumption and with the exposure to asados (open fire used for barbequing meat). This observation led the authors to conclude that the population could be exposed to certain levels of PAHs through tobacco smoking, as well as mate drinking and inhaling asado smoke. The presence of different genotypes was strongly associated with the levels of BP metabolite, 1-hydroxypyrene glucuronide (46), in urine.

In 1985, the presence of BP was assessed in samples of commercial brands of yerba mate (47). Concentrations of BP as high as $461 \mu \mathrm{g} / 1 \mathrm{Kg}$ dry mate were found; lower concentrations were found in the prepared beverage.

Zuin et al. reported an effective and simple procedure to analyze PAHs in mate infusions. The method found 15 PAHs in 11 mate brands available on the market in Brazil (48).

In 2008, a study measured PAHs in mate brands on the market in Brazil (49). The researchers found that mate leaves contained $\mathrm{PAH}$ concentration ranging from 2-11 times that of green tea leaves.
High mass fractions of carcinogenic PAHs were found, not only in dry leaves, but also in hot and cold mate infusions. The PAH measurements were of good quality and the estimation of its intake mimicked real-life consumption.

Preliminary results of a study carried out on esophageal cancer patients highlighted the presence of polymorphisms in enzymes of the P450 cytochrome group in the esophageal mucosa (50). Some of these polymorphisms were different from the ones found previously in other populations. These enzymes are involved in the metabolism of polycyclic aromatic hydrocarbons and nitrosamines, both substances capable of promoting esophageal tumors in animals. The enzymatic polymorphisms together with certain mutations encountered could explain some of the differences in the risk of esophageal cancer among different populations groups.

To understand the possible injuries due to mate intake, apart from those that could be ascribed to temperature, a study was carried out on experimental animals, exposing rats to mate drinking for the remainder of their lives (51). The mate infusion was administered at room temperature, after having been prepared with hot water. A histological examination of the upper aero-tract, stomach, esophagus, duodenum, pancreas, bladder, and kidney was conducted five months into the experiment. Significant differences were found, especially in the incidence of tracheitis and bronchiolitis, between the groups that drank mate and the controls that drank only water. There was only one occurrence of a tumor, a mediastinal mesothelioma. This study indicated that, at least for this animal model, continuous mate consumption during a large part of its life, could affect the upper aerodigestive tract, but was not causing tumors in the esophagus, oral cavity, bladder, or kidneys.

The effect of drinking hot water was studied in an interesting experimental model (52). It found that, for F344 rats, drinking tea had a protective effect against esophageal carcinogenesis induced by N-nitrosomethylbenzylamine. This protective effect of substances present in tea was inhibited by the action of hot water (over $55^{\circ} \mathrm{C}$ ), and it was concluded that, in this model, drinking hot water increased the risk of esophageal cancer.

Experimental, in vitro. The impact of heat on the esophageal epithelium was studied on sections of rabbit esophagus mounted on culture chambers that imitate the conditions of in vivo hot intakes (53). The study showed that, although the oral cavity partially modulates the temperature of the liquid that arrives to the esophagus, the structure and the functions of the esophageal epithelium can be damaged by heat stress. A study on genotoxicity using Saccharomyces cerevisiae model (54) found that the treatment of the cultures with mate infusion at $30^{\circ} \mathrm{C}$ was only capable of inducing a very low mutagenic effect. The highest mutagenic effect found for this model was obtained by hyperthermia $\left(54^{\circ} \mathrm{C}\right)$. This effect was also dependant on time of exposure. The hot caffeine was also observed to be mutagenic to the system. The mutagenic effect was lower than hyperthermia alone, but higher than the one observed due to the action of mate at $54^{\circ} \mathrm{C}$. The authors suggested that the hot caffeine and mate infusions could decrease the mutagenic effect of the hyperthermia by leading the lesions induced in the DNA into an error-free reparation system.

Aqueous extracts of Ilex paraguariensis were observed (55) to be genotoxic for Escherichia coli and Salmonella typhimurium, but the addition of $\mathrm{S} 9$ microsomal fraction, capable of intervening in various metabolic steps, counteracted the genotoxic activity. The mate extracts also produced an increased number of chromosomal aberrations in human lymphocytes. On the other hand, the capacity of mate extracts to inhibit cellular proliferation through its content in flavonoids has also been suggested (56). The flavonoids, among which chlorogenic acid is the most important in mate extracts, were able to inhibit the proliferation of a human oral carcinoma cell line through the inhibition of topoisomerase II. The total content of flavonoids varied among the commercial brands studied, and no correlation was found between their quantity and the degree of inhibition of topoisomerase in cell cultures.

\section{DISCUSSION AND CONCLUSIONS}

Mate drinking is very common in some parts of South America, and several studies in Argentina, Brazil, and Uruguay have examined the possible role of mate in cancer of the esophagus, larynx, and oropharynx $(6-8,10,14,15)$. Many publications are analyses of epidemiological studies carried out in Uru- 
guay, beginning in 1985 . The same group of authors, with occasional contributions of investigators from other countries, participated in the studies.

In general, almost all epidemiological studies included in this review shared similar methodology: hospital-based, case-control studies where participants were personally interviewed on the main risk factors, using similar questionnaires. Controls were recruited from among hospital patients suffering from diseases apparently not related with the risk factors in question. Choosing to use hospitalized controls could be a cause of confounding in the results. From a methodological point of view, it would have been more appropriate to use subjects from the general population in the control groups, but this would probably have added a significant complexity to the logistics of the studies.

The tobacco and alcohol consumption habits, fresh vegetables and fruits intake, and tea, coffee, and mate drinking were shown, in general, to be mutually correlated. Even if the presence of possible biases were controlled at the moment of analysis, the results could be influenced by residual confounding. The synergic action between mate, alcohol, and tobacco was a clear result in several studies.

An important source of inaccuracy regarding the volume of mate consumed might be simply the challenge of remembering how much one has drunk, especially if estimating over the course of a lifetime. Moreover, in different studies, mate consumption was expressed in different units, adding to the difficulty of drawing accurate comparisons among them.

Many of the studies used a general questionnaire designed to find associations between dietary and occupational factors and cancer. If a questionnaire specific to mate consumption were used, estimates of the risks might be more accurate. New studies using questionnaires focused on mate consumption are recommended to achieve more precise results.

It is unlikely that the participants' responses regarding the habit of drinking mate (essentially the quantity and temperature) were influenced by prior knowledge of its health effects-public awareness of the issue is low. Past studies referencing the issue of hot mate, especially those linking it to cancer, were not widely disseminated. However, future studies should take into account that awareness of the possible association of hot mate with the risk of tumors is increasing and responses may be biased in the future.

In most publications reviewed, there is a lack of data regarding the socioeconomic level of individuals interviewed. However, it was found that for esophageal cancer, the socioeconomic level was inversely related to risk and directly linked to alcohol consumption, nutritional deficiencies, tobacco habit, poor oral hygiene, and infections associated with some types of agents (20).

In interpreting the epidemiological results, the mechanisms mentioned were the temperature of consumption and/or the chemical content of the mate itself. The risk for esophageal cancer due to hot mate consumption-as mate con bombilla or mate cocido-and the absence of effect from cold mate $(5,7,13-15)$ sustain the hypothesis of a thermal action as the cause of the increased risk. This hypothesis agrees with observations reported from an area in Iran where the incidence of esophageal cancer is high and very hot tea is drunk (22). It has also been postulated that the contact of hot liquids with the esophageal mucosa could increase gastric reflux, causing further damage from gastric acid (22).

Thermal injury caused by hot drinks was very difficult to investigate accurately because, in general, there was no exact, objective measurement of the temperature at which mate was drunk. A lack of precise measurement of mate temperature on contact with the different tissues could lead to errors and complexity when comparing studies. The temperature of the beverage was, in general, self-evaluated, defined subjectively as "warm," "hot," and "very hot," and these categories presented only limited correlation with thermometer readings (17).

In addition, the quantity of water added to the quantity of leaves when preparing mate con bombilla varies from person to person. This presents a problem for inter- and intra-study comparisons. Likewise, since drinking mate in South America is often a social activity during which a group of drinkers partake from the same vessel, estimations of volume ingested by the individual can be inaccurate. Moreover, the size of the mate vessel can differ, adding to the imprecision.

The thermal injury hypothesis does not validly explain an excess of cancer risk in organs with which the hot beverage does not come into direct contact. In a study where an increased risk of bladder cancer was found relative to the daily intake of mate, the results may have been biased by including patients with other tumors as controls (34).

Different concentrations of PAHs were found in yerba mate leaves of different commercial brands, and in cold and hot infusions $(48,49)$. These results could support the hypothesis that the cancer risk associated with mate intake could be related not only to its temperature, but also its level of carcinogenic compounds. The more traditional mate con bombilla involves adding water to the same batch of leaves several times and drinking several cups consecutively. This could expose the mate drinker to a higher level of PAHs, than they would otherwise be exposed to if the drink were prepared once, as is the case with common tea, and the leaves discarded. It would be interesting to know the PAH levels of the various different brands and consumption habits, as well as the PAH level yielded by different processing techniques employed to dry, roast, and enhance the flavors of the fresh leaves $(1,2)$. Differences in these processes could produce differing levels of contaminants in the final products. However, the results of the genotoxic studies of Ilex paraguariensis extracts were not homogeneous (54-56).

In conclusion, there is no sound population-based case-control study on mate consumption as a risk factor for cancer available. This, coupled with the range of results on mate risk, make assessing the etiological fraction difficult.

The role that drinking of hot beverages plays on increasing the risk of cancer of the esophagus, larynx, and oral cavity seems to be supported by the results of several epidemiological studies, conducted mainly in South American countries. The temperature might act per se damaging the mucosa, or the heat may be accelerating certain metabolic reactions, including enhancing the effect of carcinogens, such as tobacco and alcohol. Thermal injury may be increasing gastric reflux, promoting contact with other irritants and carcinogenic agents. Moreover, contaminants, such as carcinogenic PAHs, present in processed mate support the hypothesis that in addition to temperature, carcinogens in processed leaves may be playing a role in cancer risk.

Bibliographic sources were widely and exhaustively searched up to August 2008, taking into account published papers and books from a variety of disciplines. There may have been some com- 
munications from scientific meetings that were not included as data sources, but it is unlikely this would produce a bias in our conclusions.

More research needs to be done before a definitive statement can be made regarding cancer risk associated with any of the various forms of mate consumption. Future research should include:

- Population-based studies;

- Collection of data on consumption of tobacco, alcohol, hot drinks, fresh fruit, and vegetables;

\section{REFERENCES}

1. Heck CI, Gonzalez de Mejía E. Yerba Mate (Ilex paraguarienses): A comprehensive review on chemistry, health implications, and technological considerations. J Food Sci. 2007;7 2(9):R138-51.

2. Instituto Nacional de la Yerba Mate. Available from: http://www.inym.org.ar/inym/ imagenes/Trabajos_Realizados/recopilacion. pdf. Accessed on 15 August 2008.

3. International Agency for Research on Cancer. Coffee, tea, methylxantines and methylglyoxal. In: IARC Monographs on the evaluation of carcinogenic risks of chemicals to humans. IARC;1991. (Scientific Publication 51).

4. International Agency for Research on Cancer. Cancer incidence in five continents VIII. Lyon: IARC; 2002. (Scientific Publications 155).

5. Vassallo A, Correa P, De Stefani E, Correa P, Cendan M, Zavala D et al. Esophageal cancer in Uruguay: a case control study. J Natl Cancer Inst. 1985;75(60):1005-9.

6. Victora CG, Muñoz N, Day NE, Barcelos LB, Peccin DA, Braga NM. Hot beverages and esophageal cancer in Southern Brazil: a case control study. Int J Cancer. 1987;39:710-6.

7. De Stefani E, Muñoz N, Estève J, Vasallo A, Victora CG, Teuchmann S. Mate drinking, alcohol, tobacco, diet, and esophageal cancer in Uruguay. Cancer Research. 1990;50:426-31.

8. Castelletto R, Castellsague $X$, Muñoz N, Iscovich J, Chopita N, Jmelnitsky A. Alcohol, tobacco, diet, mate drinking, and esophageal cancer in Argentina. Cancer Epidemiol Biom Prev. 1994;3:557-64.

9. De Stefani E, Deneo-Pellegrini H, Ronco AL, Boffetta P, Brennan P, Muñoz N et al. Food groups and risk of squamous cell carcinoma of the esophagus: a case-control study in Uruguay. British J Cancer. 2002;89:1209-14.

10. Sewram V, De Stefani E, Brennan P, Boffetta P. Maté Consumption and the risk of squamous cell esophageal cancer in Uruguay. Cancer Epidemiol Biom Prev. 2003;12:508-13.

11. Ronco AL, Barrios E, Fierro L, Balbi J, Larrinaga MT, De Stéfani E. Risk factors for esophageal cancer in non-smokers and nondrinkers: a case-control study in Uruguay. Rev Bras Epidemiol. 2004;7(4):383-9.

12. Putz A, Hartmann AA, Fontes PRO, Alexandre COP, Silvera DA, Klug SJ et al. TP53 Mutation pattern of esophageal squamous call carcinomas in high risk area (Southern Brazil): role of life style factors. Int J Cancer. 2002;98: 99-105.

13. Muñoz N, Victora CG, Crespi M, Saul C, Braga NM, Correa P. Hot maté drinking and precancerous lesions of the esophagus: an endoscopic survey in southern Brazil. Int J Cancer. 1987;39:708-9.

14. Rolón PA, Castellsagué X, Benz M and Muñoz N. Hot and cold mate drinking and esophageal cancer in Paraguay. Cancer Epidemiol Biom Prev. 1995;4:595-605.
15. Castellsague X, Munoz N, De Stefani E, Victora CG, Castelletto R, Rolon PA. Influence of maté drinking, hot beverages and diet on esophageal cancer risk in South America. Int J Cancer. 2000;88:658-64.

16. Dc Jong UW, Day NE, Mounier-Kuhn PL, Haguenauer JP. The relationship between the ingestion of hot coffee and intraesophageal temperature. Gut. 1972;13:24-30.

17. Silva de Barros S, Sörensen Ghisolfi E, Perondi Luz L, Guinsburg Barlem G, Machado Vidal R, Herz Wolff F et al. Mate (chimarrão) é consumido em alta temperatura por população sob risco para o carcinoma epidermóide de esôfago. Arq gastroenterol. 2000;37:25-30.

18. Kinjo Y, Cui Y, Akiba S, Watanabe S, Yamaguchi N, Sobue T, et al. Mortality risks of esophageal cancer associated with hot tea, alcohol, tobacco and diet in Japan. J Epidemiol. 1998;8:235-43.

19. Kreimer AR, Randi G, Herrero R, Castellsague $X$, La Vecchia C, Franceschi $S$ et al. Diet and body mass, and oral and oropharyngeal squamous cell carcinomas: analysis from the IARC multinational case-control study. Int J Cancer. 2006;118(9):2293-7.

20. Gonzalez CA, Pera G, Agudo A, Bueno-deMesquita HB, Ceroti M, Boeing $\mathrm{H}$ et al. Fruit and vegetable intake and the risk of stomach and esophagus adenocarcinoma in the European Prospective Investigation into Cancer and Nutrition (EPIC-EURGAST). Int J Cancer. 2006;118:2559-66.

21. Kamangar F, Malekzadesk R, Dawsey SM, Saisi F. Esophageal cancer in Northeastern Iran: a review. Arch Iranian medicine. 2007;10:70-82

22. Ghadirian P. Thermal irritation and esophageal cancer in Northern Iran. Cancer. 1987;60: 1909-14.

23. Wang JM, Xu B, Rao JY, Shen HB, Xue HC, Jiang QW Diet habits, alcohol drinking, tobacco smoking, green tea drinking, and the risk of esophageal squamous cell carcinoma in the Chinese population. Eur J Gastroenterol Hepatol. 2002;19:171-6.

24. Kreimer AR, Clifford GM, Boyle P, Franceschi S. Human papillomavirus types in head and neck squamous cell carcinomas worldwide: a systematic review. Cancer Epidemiol Biom Prev. 2005;14(2):467-75.

25. Pintos J, Franco EL, Oliveira BV, Kowalski LP, Curado MP, Dewar R. Maté, coffee, and tea consumption and risk of cancers of the upper aerodigestive tract in southern Brazil. Epidemiology. 1994;5:583-90.

26. De Stéfani E, Correa P, Oreggia F, Leiva J, Rivero S, Fernandez G, et al. Risk factors for laryngeal cancer. Cancer. 1987;60:3087-91.

27. De Stefani E, Correa P, Oreggia F, DeneoPellegrini H, Fernández G, Zavala D. Black tobacco, wine and mate in oropharyngeal cancer. A case-control study from Uruguay. Rev Epidem Sante Publ. 1988;36:389-94.
- A method to precisely measure volume and temperature of mate intake.

Acknowledgement. The authors wish to thank Marina Ghea for her assistance with corrections to the manuscript.
28. Oreggia F, De Stefani, E, Correa P, Fierro L. Risk factors for cancer of the tongue in Uruguay. Cancer. 1991;67:180-3.

29. Wunsh-Filho V, Archer de Camargo E. The burden of mouth cancer in Latin America and the Caribbean: Epidemiologic Issues. Semin Oncol. 2001;28:158-68.

30. Wunsch-Filho V. The epidemiology of oral and pharynx cancer in Brazil. Oral Oncol. 2002;38: 737-46.

31. Franco EL, Kowalski LP, Oliveira BV, Curado MP, Pereira RN, Silva ME et al. Risk factors for oral cancer in Brazil: a case-control study. Int J Cancer. 1989;43:992-1000.

32. Goldenberg D. Maté: a risk factor for oral and oropharyngeal cancer. Oral Oncol. 2002;38:646-9.

33. Goldenberg D, Golz A, Zvi Joachims H. The beverage maté: a risk factor for cancer of the head and neck. Head \& Neck. 2003;25: 595-601.

34. De Stefani E, Correa P, Fierro L, Fontham E, Chen V and Zavala D. Black tobacco, maté, and bladder cancer. A case-control study from Uruguay. Cancer. 1991;67:536-40.

35. Bates MN, Hopenhayn C, Rey OA, Moore LE. Bladder cancer and mate consumption in Argentina: A case-control study. Cancer Letters. 2007;246(1-2):268-73.

36. Bates MN, Rey OA, Biggs ML, Hopenhayn C, Moore LE, Kalman D et al. Case-control study of bladder cancer and exposure to arsenic in Argentina. Amer J Epidemiol. 2004;159(4): 381-89.

37. Iscovich J, Castelleto R, Esteve J, Muñoz N, Colanzi R, Coronel A et al. Tobacco smoking, occupational exposure and bladder cancer in Argentina. Int J Cancer. 1987;40:734-40.

38. De Stefani E, Fierro L, Mendilaharsu M, Ronco A, Larrinaga MT, Balbi JC et al. Meat intake, 'mate' drinking and renal cell cancer in Uruguay: a case-control study. Br J Cancer. 1998;78:1239-43.

39. De Stefani E, Fierro, Pelayo Correa, Fontham E, Ronco A, Larrinaga M, Balbi J and Mendilaharsu M. Mate drinking and risk of lung cancer in males: a case-control study from Uruguay. Cancer Epidemiol Biom Prev. 1996;5:515-9.

40. Sichieri R, Everhart JE, Mendonça. Dieta e mortalidade para os tipos mais freqüentes de câncer no Brasil: um estudo ecológico. Cad Saúde Públ (Rio de Janeiro). 1996;12(1):53-9.

41. Victora, CG, Muñoz N, Horta BL, Ramos EO. Patterns of maté drinking in a Brazilian city. Cancer Res. 1990;50:7112-5.

42. Ebel Ortiz CG, Ebel Ortiz MD, Vanni N, Gorodner A. Estudio de neoplasia de esófago en el nordeste argentino. Rev Posgrado Via Cátedra Med. 2006;Mayo(157):1-2.

43. Dietz J, Dile AS, Prolla JC, Furtado CD, Furtado AD. Pesquisa de micronúcleos na mucosa esofágica e sua relação com fatores de risco ao câncer de esôfago. Rev Ass Med Brasil 2000;46(3):207-11. 
44. Roffo AH. Cáncer producido por el alquitrán del mate. Bol Inst Med Expt Cancer. 1941; 18(56):5-20.

45. Fagundes FG, Abnet CC, Strickland PT, Kamangar F, Roth MJ, Taylor PR et al. Higher urine 1-hydroxypyrene glucuronide (1OHPG) is associated with tobacco smoke exposure and drinking maté in healthy subjects from Rio Grande do Sul, Brazil. BMC Cancer. 2006;6:139.

46. Abnet CC, Fagundes RB, Strickland PT, Kamangar F, Roth MJ, Taylor PR et al. The influence of genetic polymorphisms in $A h r$, CYP1A1, CYP1A2, CYP1B1, GST M1, GST T1 and UGT1A1 on urine 1-hydroxypyrene glucuronide concentrations in healthy subjects from Rio Grande do Sul, Brazil. Carcinogenesis. 2007;28:112-17.

47. Ruschenburg U. Benzo[a]pyrene content of coffee and some other foodstuffs. In: $11^{\mathrm{e}}$ Colloque Scientifique International sur le Café. Paris: Association Internationale du Café. 1985. Pp. 205-212.

48. Zuin VG, Montero L, Bauer C, Popp P. Stir bar sorptive extraction and high-performance liquid chromatography-fluorescence detec- tion for the determination of polycyclic aromatic hydrocarbons in Mate teas. J Chromatogr. 2005;1091:2-10.

49. Kamangar F, Scantz MM, Abnet CC, Fagundes RB, Dawsey SM. High levels of carcinogenic polycyclic aromatic hydrocarbons in mate drinks. Cancer Epidemiol Biomarkers Prev. 2008;17:1262-8.

50. Ribeiro Pinto LF, Teixeira Rossini AM, Mattos Albano R, Felzenszwalb I, de Moura Gallo $\mathrm{CV}$, Acatuassú Nunes R et al. Mechanisms of esophageal cancer development in Brazilians. Mutation Res. 2003;544:365-73.

51. Vargas Alves RJ, Chacur R, Buzzatti C, Caruccio Hübner MI, Dias De Oliveira M, Maeso Montes TH et al. Estudo experimental da erva mate (Ilex paraguariensis) como agente etiológico deneoplasia do trato aéro-digestivo: aspectos histológicos e evolução ponderal. Rev Iniciação Científica ULBRA. 2005:4:95-102.

52. Li ZG, Shimada Y, Sato F, Maeda M, Itami A, Kaganoi J, Komoto I, Kawabe A et al. Promotion effects of hot water on N-nitrosomethylbenzylamine induced esophageal tumorigenesis in F344 rats. Oncol Rep. 2003;10:421-6.
53. Tobey NA, Sikka D, Marten E, Caymaz-Bor C, Housseini SS, Orlando RC. Effect of heat stress on rabbit esophageal epithelium. Am J Physiol Gastrointest Liver Physiol. 1999;272:1322-30.

54. Candreva EC, Keszenman DJ, Barrios E, Gelos U, Nunes E. Mutegenicity induced by hyperthermia, hot mate infusion, and hot caffeine in Saccharomyces cerevisiae. Cancer Res. 1993; 53(23):5750-3.

55. Fonseca CA, Otto SS, Paumgartten FJ, Leitao AC. Nontoxic, mutagenic, and clastogenic activities of Mate-Cimarrao (Ilex Paraguariensis). J Environ Pathol Toxicol Oncol. 2000; 19(4):333-46.

56. Gonzalez de Mejia E, Song YS, RamirezMares MV, Kobayashi H. Effect of yerba mate (Ilex paraguariensis) tea on topoisomerase inhibition and oral carcinoma cell proliferation. J Agric Food Chem. 2005;53:1966-73.

Manuscript received on 25 March 2008. Revised version accepted for publication on 4 November 2008 .

RESUMEN Objetivo. Identificar posibles vínculos entre el consumo de mate y el cáncer, en particular de esófago, laringe y cavidad bucal.

Cáncer y consumo de yerba mate: revisión de posibles asociaciones

Métodos. Se realizó una revisión de la bibliografía publicada hasta agosto de 2008 sobre el riesgo carcinogénico del consumo de mate en dos bases de datos, MEDLINE y TOXLINE. Se revisaron las referencias bibliográficas de los artículos para encontrar fuentes adicionales y se buscó por cada autor que hubiera publicado sobre el tema. Los estudios epidemiológicos se presentan según la localización del cáncer, los trabajos experimentales se examinan en secciones separadas y en la discusión se combinaron los datos epidemiológicos y experimentales.

Resultados. Casi todos los estudios epidemiológicos siguieron la misma metodología: estudios de casos y controles basados en hospitales donde se entrevistaba personalmente a los participantes acerca de los principales factores de riesgo mediante cuestionarios similares. En algunos estudios se encontró una asociación entre la temperatura de la infusión de mate y el riesgo de cáncer bucal, de esófago y de laringe, mientras que unos pocos se concentraron en los contaminantes carcinogénicos introducidos durante el procesamiento industrial de las hojas. El tipo de cáncer más frecuentemente mencionado en asociación con el mate caliente en bombilla (tomado a través de una cañita metálica) fue el de esófago. El tamaño de la muestra, la evaluación de la exposición, el método de análisis y la calidad variaron de un estudio a otro. Los resultados variaron considerablemente. Se estimó un mayor riesgo (razón de posibilidades $=34,6$ ) en las mujeres que tomaban $1 \mathrm{~L}$ diario o más; en los hombres este riesgo fue solo de 4,8. El riesgo aumentó con el tiempo de consumo, la cantidad diaria y la temperatura de la infusión consumida. En algunos estudios se observó una clara sinergia entre el consumo de mate, alcohol y tabaco, mientras que en otros las deficiencias nutricionales y la inadecuada higiene bucal desempeñaron un papel importante. No se observó aumento en el riesgo asociado con el consumo de bebidas frías de mate. Conclusiones. Varios estudios epidemiológicos parecen respaldar el papel de las bebidas calientes de mate en el aumento del riesgo de cáncer de esófago, laringe y cavidad bucal. La temperatura podría influir al dañar la mucosa o acelerar algunas reacciones metabólicas, entre ellas con algunas sustancias carcinogénicas del tabaco y el alcohol. No obstante, no se encontraron estudios robustos de casos y controles basados en la población sobre el consumo de mate como factor de riesgo de cáncer. Esto, unido a los resultados encontrados sobre el riesgo del consumo de mate, hace difícil estimar su fracción etiológica. Se requieren más investigaciones antes de establecer definitivamente el riesgo de cáncer asociado con alguna de las diversas formas de consumo de mate. Se deben realizar estudios basados en la población, obtener más datos sobre el consumo de tabaco, alcohol, bebidas calientes, frutas frescas y vegetales y se deben emplear métodos que permitan medir con precisión el volumen y la temperatura del mate consumido.

Palabras clave Neoplasias laríngeas, neoplasias esofágicas, neoplasias faríngeas, Ilex paraguariensis, revisión, Argentina, Brasil, Paraguay, Uruguay. 